\title{
PARC/CCLI8 is Associated with Inflammation, Emphysema Severity and Application of Inhaled Corticosteroids in Hospitalized COPD Patients
}

\section{Hongxia Duan \\ Long Liang \\ Xinyang Liu \\ Shuanshuan Xie \\ Changhui Wang}

Department of Respiratory Medicine, Shanghai Tenth People's Hospital, Tongji University School of Medicine, Shanghai, People's Republic of China
Correspondence: Shuanshuan Xie; Changhui Wang

Department of Respiratory Medicine, Shanghai Tenth People's Hospital, Tongji University School of Medicine, \#30I, Mid

Yanchang Road, Shanghai, People's

Republic of China

Tel/Fax +86-2I-6630l685

Email xieshuanshuan@aliyun.com; wangchang-hui@hotmail.com
Background: Pulmonary and activation-regulated chemokine (PARC) also named CCchemokine ligand 18 (CCL18) is a lung-predominant inflammatory protein that is found in serum. The relationship of PARC/CCL18 with the chronic obstructive pulmonary disease (COPD) is not fully understood. The aim of the present study is to analyze the expression of PARC/CCL18 in COPD.

Methods: Ninety-eight hospitalized COPD patients and 60 healthy volunteers from January 2019 to December 2019 were recruited in this retrospective study. Gender, age, height, weight, disease duration, smoking status, blood cell classification and count, length of hospital stay (LOS), symptom score, including COPD Assessment Test (CAT) score, modified British Medical Research Council (mMRC) score, lung function and therapy were recorded and serum PARC/CCL18 was analyzed by ELISA. The correlation between symptom score, blood cell classification and count, CRP, lung function parameters and serum levels of PARC/CCL18 and ROC curves of PARC/CCL18 levels and inhaled corticosteroids (ICS) were accessed.

Results: It was found that serum PARC/CCL18 level in hospitalized COPD population was significantly higher than that in healthy people $(\mathrm{p}=0.003)$. COPD patients with emphysema had significantly higher serum level of PARC/CCL18 than those without emphysema $(\mathrm{p}=0.049)$. Total lung capacity (TLC) and residual volume (RV)/TLC had positive correlation with serum level of PARC/CCL18 ( $\mathrm{p}=0.001,0.020$, respectively). Furthermore, serum PARC/CCL18 level was predictive for the application ICS $(\mathrm{p}=0.003)$ and related to C-reactive protein $(\mathrm{p}<0.0001)$ in hospitalized COPD patients.

Conclusion: PARC/CCL18 is associated with the severity of inflammation and emphysema in COPD. Furthermore, PARC/CCL18 is a predictor of ICS application in the treatment of hospitalized COPD patients.

Keywords: PARC/CCL18, COPD, inflammation, pulmonary function, inhaled corticosteroids

\section{Background}

Chronic obstructive pulmonary disease (COPD) is a severe chronic disease affecting over 170 million people ${ }^{1}$ and responsible for over 3 million deaths each year globally, ${ }^{2}$ which has had a great impact on the stress on the health burden worldwide. In this setting, reliable and reproducible biomarkers play a key role in the management of COPD. ${ }^{3}$ Based on the characteristics of rapid acquisition and easy standardization, blood is the most attractive organ for obtaining biomarkers. However, its application may be limited in pulmonary diseases because most 
serum proteins are secreted by the bone marrow, the liver and other non-pulmonary organs. Fortunately, pulmonary and activation-regulated chemokine (PARC), which also named CC-chemokine ligand 18 (CCL18), is a 7-kD protein secreted in the lungs predominantly and a member of the $\mathrm{CC}$ chemokine family containing two-disulfide bonds (Cys10-Cys34 and Cys11-Cys50). ${ }^{4,5}$

Chemokines play a crucial part in inflammation and immunity by regulating the movement of leukocytes. ${ }^{6}$ PARC/CCL18 also has chemotactic activity toward human naive $\mathrm{T}$ cells without doubt. ${ }^{4,7}$ Besides, it also attracts Th2 cells, B cells, immature dendritic cells, NK cells, basophils, bone marrow progenitor cells, fibroblasts and so on. ${ }^{8-12}$ Although, indeed, the exact biological function of PARC/CCL18 is unclear, serum levels are elevated in acute coronary syndromes, idiopathic pulmonary fibrosis and childhood acute lymphoblastic leukemia. ${ }^{13-15}$ However, the relationship of PARC/CCL18 with COPD is currently unknown ${ }^{16}$ while early studies indicated the lung tissue express PARC/CCL18 highly and constitutively in humans. ${ }^{6,17}$

Evaluated by forced expiratory volume in one second (FEV1), forced vital capacity (FVC) and the FEV1 to FVC ratio (FEV1/FVC), lung function is an impersonal indicator of general respiratory health and a significant long-term predictor in COPD patients. ${ }^{18-22}$ There were some studies got promising data and draw the conclusion that serum PARC/CCL18 level was significantly associated with reduced body mass index (BMI), airflow obstruction, dyspnea, acute exacerbations and health outcomes. ${ }^{23-25}$ There was also a genome-wide association study of lung function phenotypes in a founder population provided an evidence of the associations of PARC/CCL18 with FEV1/FVC and indicated PARC/CCL18 is involved in anti-microbial immunity in airway mucosa and to contribute to lung function phenotypes in healthy, unselected subjects. ${ }^{26}$

As far as we know, the data directly discussing the relationship of PARC/CCL18 with lung function and therapy in COPD is limited. ICS application in COPD is controversial. It reduces inflammation in the airways but also increases the risk of pulmonary infection, and oropharynx fungal infection. ${ }^{27-29}$ Therefore, our aim is to examine the level of serum PARC/CCL18 in COPD patients and in normal population and analyze the association between serum PARC/CCL18 and clinical symptoms, pulmonary function, blood cell classification and counting, therapy in COPD, comprehensively. To achieve this end, serum samples from COPD patients and healthy volunteers were collected. The correlations between serum PARC/CCL18 and relevant test results were studied.

\section{Methods}

\section{Study Cohort and Clinical Parameters}

The study was approved by the Ethics Committee of Shanghai Tenth People's Hospital (No. 20KT75). All experiments performed in this study are in accordance with the approved ethical standards and the volunteers' informed consents were obtained. COPD patients in Department of Respiratory Medicine of Shanghai Tenth People's Hospital from January 2019 to December 2019 were recruited in this retrospective study. The subject's COPD diagnosis was based on the ratio of postbronchodilator FEV1 to FVC $<0.70$ according to the Global Initiative for Chronic Obstructive Lung Disease (GOLD) guideline standards. Exclusion criteria: asthma, tuberculosis, pneumonia or other site infection; connective tissue disease, arthritis, inflammatory bowel disease; complicated with malignant tumor; coronary artery disease; lack of PARC/CCL18 data. COPD Assessment Test (CAT) and modified British Medical Research Council (mMRC) scores were used to assess the symptom severity of patients. All the patients were diagnosed with, assessed, treated and followed by occupational respiratory physicians and clinical, laboratory, lung function, therapy were systematically recorded in the Computerized Patient Record System (CPRS) at the hospital. We also enrolled 60 healthy volunteers between 35 and 60 yrs old at random who underwent routine physical examination in our hospital and serum samples were collected for healthy control. COPD patients' data of clinical, blood cell classification, lung function and therapy were obtained from CPRS. The flow chart of this study is shown in Figure 1.

\section{Systematic Assessment of COPD}

Gender, age, height, weight, disease duration, smoking status, length of hospital stay (LOS), lung function, therapy, and symptom scores, including CAT score, mMRC score were recorded. Disease onset was defined as the time when first diagnosed as COPD, and the time from disease onset to blood samples collected were defined as the disease duration. Packyears of smoking was the number of packets smoked per day times the number of years. CT images were reconstructed at $5.00 \mathrm{~mm}$ section thickness in $10 \mathrm{~mm}$ intervals and a change of low-density area showed in lung window, CT value 


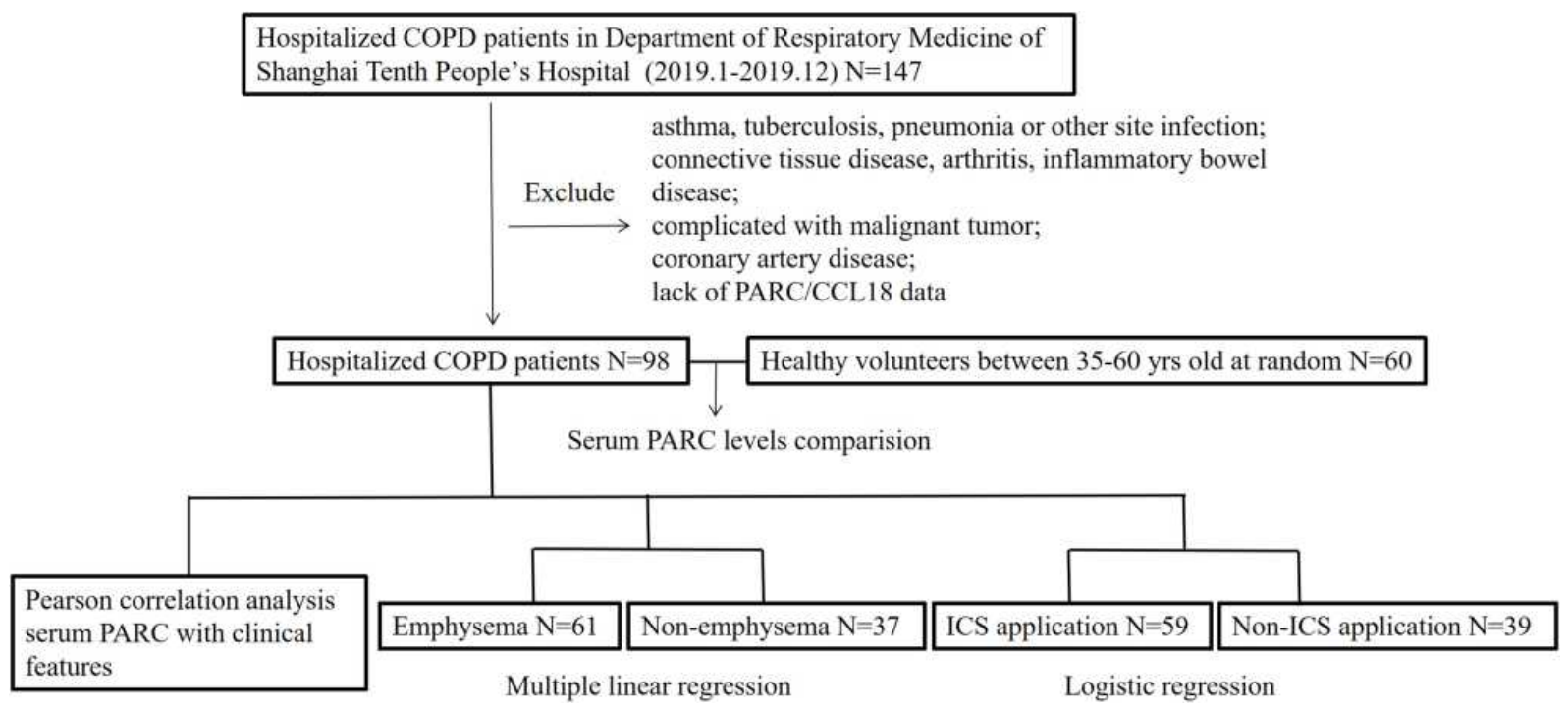

Figure I The flowchart of this study.

decreased (about $-910 \mathrm{HU}$ ), vascular texture became thinner, sparse and number reduced were defined as emphysema. The treatment for patients was decided by the attending physicians and was not particularly limited. This study focused on the treatment of inhaled corticosteroids (ICS). The guidelines for ICS application are 1) hospitalization for acute exacerbations of COPD; 2) moderately acute exacerbations of COPD greater than 1 time per year; 3) eosinophils greater than 100 per microliter. Paired serum sample, lung function were performed and collected both at the time of registration. All participants rested in a quiet condition for $30 \mathrm{~min}$ before lung function tests. Lung function was measured by pulmonary function meter (Sensormedics Inc.) before and after inhalation of short-acting $\beta$ agonist (salbutamol). Total lung capacity (TLC), residual volume (RV), forced expiratory volume in the 1st second (FEV1), forced vital capacity (FVC), peak expiratory flow (PEF), carbon monoxide diffusion capacity (DLCO) and vital capacity (VC) were measured. Lung function results were staged based on GOLD (Global Initiative for Obstructive Lung Disease) guideline. GOLD stage I (FEV1, > 80\% predicted), II (FEV1, 50-80\% predicted), III (FEV1, 30-50\% predicted), or IV (FEV1< $30 \%$ predicted) of COPD. ${ }^{30}$

\section{Human-PARC/CCLI8 ELISA}

Blood was centrifuged at 4000rpm for 5 minutes to separate the supernatant and serum samples were stored at $-80^{\circ} \mathrm{C}$ until assayed. Serum PARC/CCL18 was analyzed by enzyme immunoassay (RayBio ${ }^{\circledR}$ Human PARC ELISA Kit, USA) using serum diluted by 400 times according to the results of the preliminary experiment and the experiment was carried out in strict accordance with the experimental protocol. Serum samples from 60 healthy controls were also measured.

\section{Statistical Analyses}

All analyses were performed by SPSS version 21 (SPSS Inc. Chicago, IL) and GraphPad Prism6 (GraphPad Software, San Diego, USA). Independent sample $t$-test and Pearson's chisquare test were used to assess the baseline parameters and to evaluate the differences between the groups appropriately. Mann-Whitney test was used to assess the differences of PARC levels between COPD patients and healthy control, emphysema and non-emphysema, ICS and non-ICS application group. ANOVA statistics was used to evaluate the differences between multiple groups. Pearson correlation analysis was used to assess the correlation. Multiple linear regression was performed assessing the association between PARC and independent variables. Logistic regression was used to assess the predicted ability of PARC on ICS application. Receiver operating characteristic curve (ROC curve) was used to assess the predictive accuracy of ICS application. All tests were twosided and $\mathrm{p}<0.05$ was considered to be significant.

\section{Results}

\section{Demographic and Clinical Variables}

98 COPD patients and 60 healthy individuals were included in this study. Table 1 shows the clinical characteristics of the subjects. Males were more dominant among COPD patients (79.59\%). Mean serum concentration of 
Table I Clinical Characteristics of the Subjects

\begin{tabular}{|c|c|c|c|}
\hline & $\begin{array}{l}\text { COPD } \\
(n=98)\end{array}$ & $\begin{array}{l}\text { Healthy Control } \\
(n=60)\end{array}$ & p value \\
\hline Age (yrs) & $71.48 \pm 8.60$ & $63.3 I \pm 7.78$ & - \\
\hline $\begin{array}{l}\text { Male, n (\%)/ } \\
\text { Female }\end{array}$ & 78 (79.59\%) & 32 (53.33\%) & - \\
\hline $\begin{array}{l}\text { Disease duration } \\
\text { (yrs) }\end{array}$ & $10.10 \pm 8.66$ & - & - \\
\hline Pack-years & $\begin{array}{l}26.78 \\
\pm 18.58\end{array}$ & $19.54 \pm 24.17$ & - \\
\hline $\begin{array}{l}\text { Current smoker } \\
\text { (\%) }\end{array}$ & 17 (I7.35\%) & 14 (23.33\%) & - \\
\hline LOS (days) & $7.36 \pm 3.24$ & - & - \\
\hline CAT (score) & $25.07 \pm 6.40$ & - & - \\
\hline mMRC (score) & $2.69 \pm 0.97$ & - & - \\
\hline BMI $\left(\mathrm{kg} / \mathrm{m}^{2}\right)$ & $23.00 \pm 3.98$ & $22.78 \pm 3.75$ & - \\
\hline $\begin{array}{l}\text { COPD severity, } \\
\text { GOLD } \\
\text { Mild, I } \\
\text { Moderate, II } \\
\text { Serve, III } \\
\text { Very serve, IV }\end{array}$ & $\begin{array}{l}18(18.37 \%) \\
21(21.43 \%) \\
40(40.82 \%) \\
19(19.39 \%)\end{array}$ & - & - \\
\hline PARC, $\mathrm{ng} / \mathrm{mL}$ & $\begin{array}{r}162.56 \\
\pm 14.44\end{array}$ & $85.09 \pm 5.97$ & 0.003 \\
\hline
\end{tabular}

Notes: Analyzed by Mann-Whitney test. Data are presented as mean \pm SD, or number. - means data lacking or not applicable. Bold text means $p<0.05$.

Abbreviations: COPD, chronic obstructive pulmonary disease; yrs, years; LOS, length of hospital stay; CAT, COPD Assessment Test; mMRC, modified British Medical Research Council; BMI, body mass index; PARC, pulmonary and activationregulated chemokine.

PARC/CCL18 in COPD patients was $162.56 \pm 14.44 \mathrm{ng} /$ $\mathrm{mL}$, while that was $85.09 \pm 5.97 \mathrm{ng} / \mathrm{mL}$ in healthy control, and $\mathrm{p}$ value of Mann-Whitney test between them was 0.003 (Figure 2).

\section{Serum PARC/CCLI 8 and Clinical Features}

As Table 1 shows, of the 98 COPD patients, average disease duration and LOS were $10.10 \pm 8.66$ years and $7.36 \pm 3.24$ days, respectively. Mean CAT and mMRC scores were $25.07 \pm 6.40$ and $2.69 \pm 0.97$, respectively. Figure 3 shows the relationship between clinical features and serum levels of PARC/CCL18. According to mMRC score, samples were divided into 4 groups (score $=1,2,3$, 4 , respectively), and there were statistically significant differences in serum levels of PARC/CCL18 between the 4 groups ( $\mathrm{p}=0.010$, Figure $3 \mathrm{~B})$. A similar method was used for GOLD (Figure 3A), and there was no difference between the four groups (Grade I, II, III, IV, respectively, $\mathrm{p}=0.451$ ). There were statistically significant positive relationships between CAT score (Figure 3C, $r=0.26$, $\mathrm{p}=0.010$ ), disease duration (Figure $3 \mathrm{D}, \mathrm{r}=0.27, \mathrm{p}=0.016$ ) and serum levels of PARC/CCL18. The correlation between LOS (Figure 3E, $\mathrm{r}=0.13, \mathrm{p}=0.206$ ), BMI (Figure $3 \mathrm{~F}, \mathrm{r}=0.18, \mathrm{p}=0.084$ ) and serum levels of PARC/CCL18 were not statistically significant, respectively.

\section{Serum PARC/CCLI 8 and Blood Test}

Figure 4 shows the relationship between white blood cells (WBC), hemoglobin ( $\mathrm{Hb}$ ), platelet (Plt), neutrophils (Neut), neutrophil ratio (Neut\%), C-reactive protein (CRP) and serum PARC/CCL18 level, respectively. There were positive relationships between CRP $(r=0.48, \mathrm{p}<0.0001)$ and serum PARC/CCL18 values. There were no relationships between Neut\% $(\mathrm{r}=0.24, \mathrm{p}=0.017), \mathrm{Hb} \quad(\mathrm{r}=0.3, \mathrm{p}=0.027), \mathrm{WBC}$ $(\mathrm{r}=0.14, \mathrm{p}=0.170)$, Plt $(\mathrm{r}=0.10, \mathrm{p}=0.305)$, Neut $(\mathrm{r}=0.20$, $\mathrm{p}=0.046$ ) and serum PARC/CCL18.

\section{Serum PARC/CCLI8 and Lung Function}

Ninety-eight recruited patients were divided into emphysema group and non-emphysema group according to lung CT results. As Figure 5 shows, PARC/CCL18 levels were higher in the emphysema patients than non-emphysema patients in COPD (184.4 vs $117.0 \mathrm{ng} / \mathrm{mL}, \mathrm{p}=0.048$ ). Consistently, PARC/CCL18 levels were significantly associated with TLC ( $\mathrm{r}=0.46, \mathrm{p}=0.001)$ and RV/TLC ( $\mathrm{r}=0.34, \mathrm{p}=0.020)$. Compared with non-emphysema group, there were more males (57 vs $21, \mathrm{p}<0.0001)$, and higher pack-years (29.07 vs $14.26, \mathrm{p}=0.008)$, mMRC scores ( 2.85 vs $2.41, \mathrm{p}=0.025$ ), CAT scores (26.41 vs 22.79, $\mathrm{p}=0.005)$, RV (2.72 vs 1.91 , $\mathrm{p}=0.019)$, TLV (5.01 vs 4.06, $\mathrm{p}=0.012)$ and $\mathrm{RV} / \mathrm{TLV}(0.55 \mathrm{vs}$ $0.48, p=0.044$ ) in emphysema group (Table 2).

Then, a multiple linear regression was performed with PARC as dependent and emphysema, gender, CAT, mMRC, $\mathrm{RV}, \mathrm{TLC}, \mathrm{RV} / \mathrm{TLC}$ as independent variables. Using multiple linear regression we estimated emphysema, gender, CAT, mMRC, RV, TLC, RV/TLC to identify clinical indicators independently predictive of PARC levels. In our analysis, emphysema $(\mathrm{p}=0.654)$, gender $(\mathrm{p}=0.564)$, CAT $(\mathrm{p}=0.782)$, $\operatorname{mMRC}(\mathrm{p}=0.979), \mathrm{RV}(\mathrm{p}=0.296), \mathrm{TLC}(\mathrm{p}=0.657), \mathrm{RV} / \mathrm{TLC}$ $(\mathrm{p}=0.409)$ were not predictive of PARC levels. 


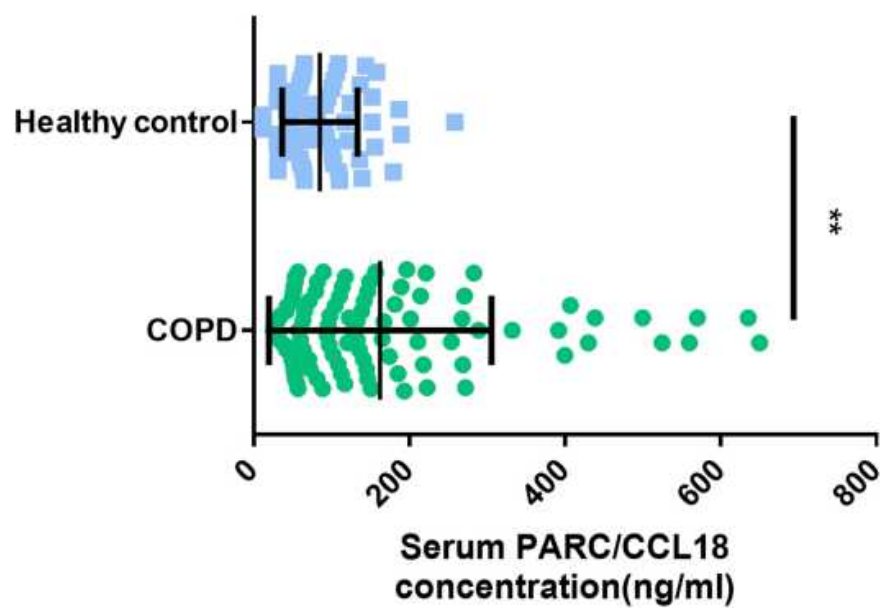

Figure 2 Comparison of serum PARC/CCLI8 concentration in COPD patients and healthy control. The central horizontal line on each box represents the average, the error bars $5 \%$ and $95 \%$. $P$-values derived from the $t$-test. **Means $p<0.01$

Abbreviations: PARC, pulmonary and activation-regulated chemokine; CCL-18, chemokine (C-C motif) ligand I8; COPD, chronic obstructive pulmonary disease.

\section{Serum PARC/CCLI8 and ICS Application}

Patients were divided into ICS group and non-ICS group according to whether they used ICS after admission. Table 3 shows the clinical characteristics of subjects in the two groups. There were no significant differences in gender, disease duration, pack-years, whether giving up smoking, CAT score, mMRC score, GOLD stage, WBC, Hb, Plt, Neut, Eos and CRP between the two groups. Furthermore, there were also no significant differences in emphysematous severity evaluated by RV, TLC and RV/TLC. Conversely, in the ICS group, age ( 73.32 vs $68.36, p=0.001)$, LOS ( 8.00 vs 6.48, $\mathrm{p}=0.020)$, serum PARC/CCL18 concentration (209.70 vs 91.30, $\mathrm{p}<0.0001)$ were significantly higher, and BMI (22.30 vs $23.99, p=0.036)$ was lower than in the non-ICS group. To assess the predicted ability of PARC on ICS application, logistic regression with ICS application as
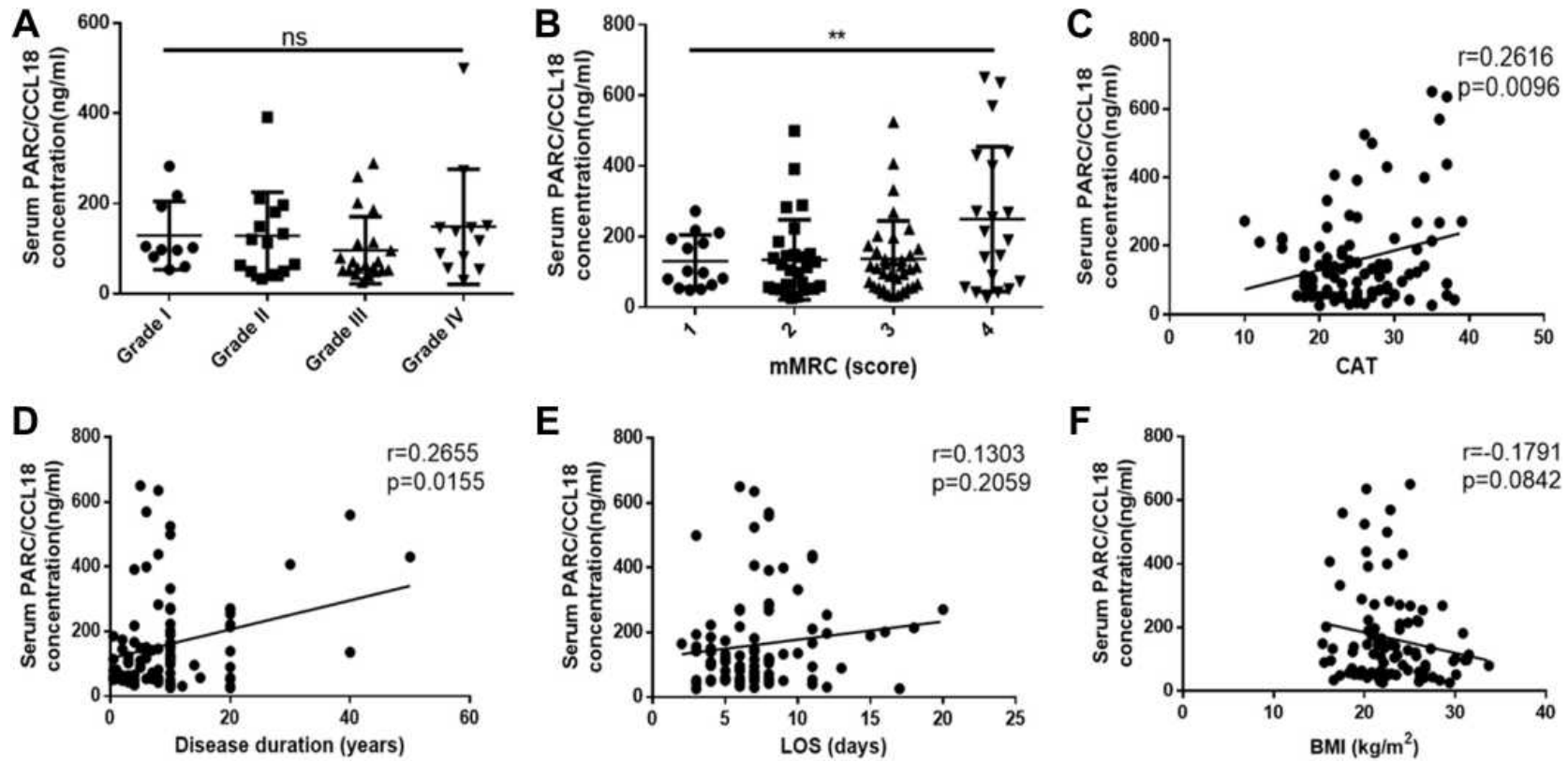

Figure 3 Comparison of serum PARC/CCLI 8 concentration in different Grade (A) and with different mMRC scores (B) of COPD patients. Relationship between CAT (C), disease duration (D), LOS (E), BMI (F) and serum PARC concentration, respectively. The central horizontal line on each box represents the average, the error bars $5 \%$ and $95 \%$, $\mathrm{p}$-values derived from the $t$-test in $(\mathbf{A})$ and $(\mathbf{B})$. $* *$ Means $\mathrm{p}<0.0 \mathrm{I}$. The line in $(\mathbf{C})$ to $(\mathbf{F})$ represents the regression line of correlation analysis, Pearson correlation coefficients of $r$-values and $p$-values were shown at the top right of the picture.

Abbreviations: COPD, chronic obstructive pulmonary disease; yrs, years; LOS, length of hospital stay; CAT, COPD Assessment Test; mMRC, modified British Medical Research Council; BMI, body mass index; PARC, pulmonary and activation-regulated chemokine. 

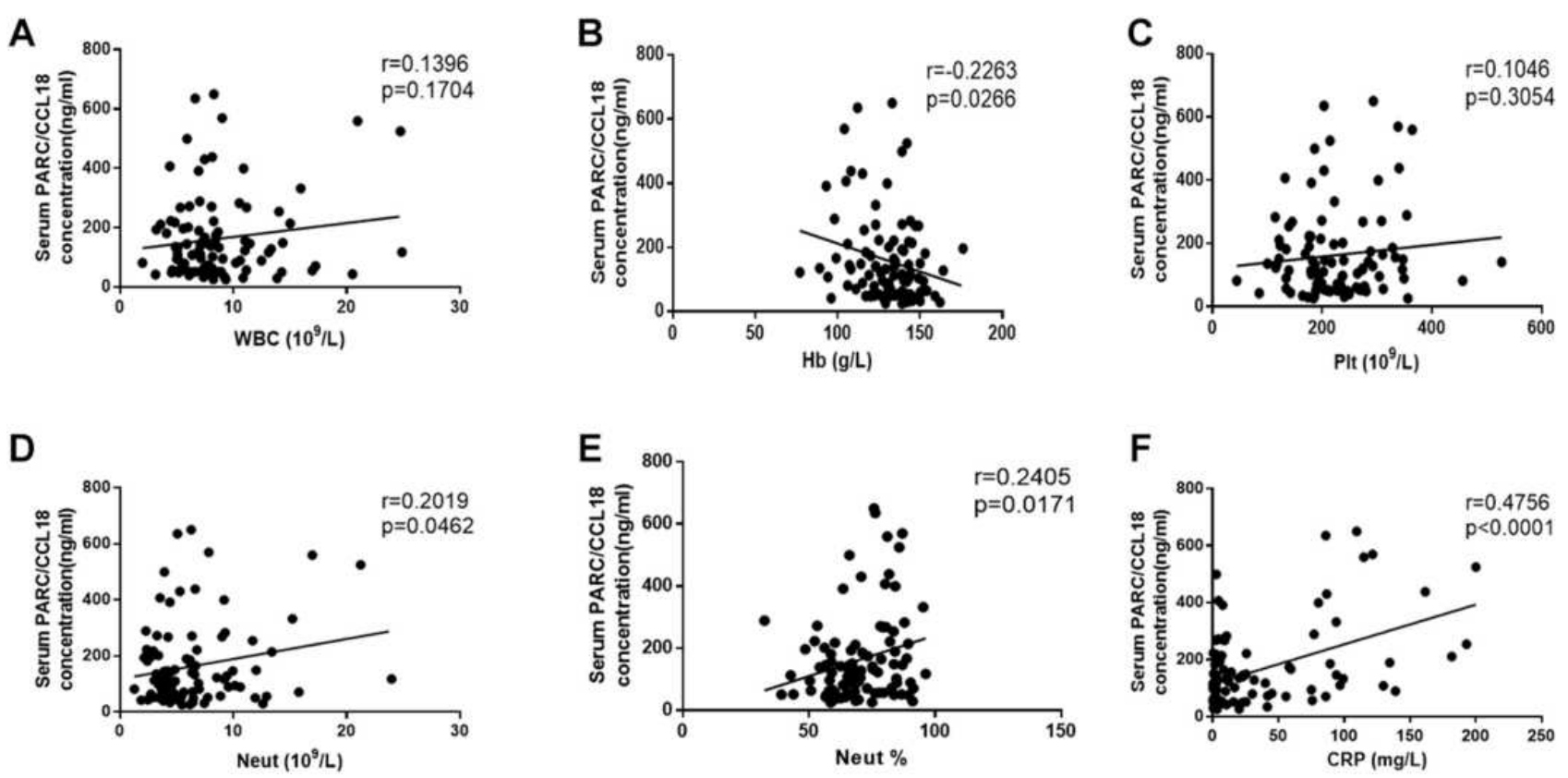

Figure 4 Correlation between WBC (A), Hb (B), Plt (C), Neut (D), Neut\% (E), CRP (F) and serum PARC/CCLI8 level, respectively. The line represents the regression line of correlation analysis, Pearson correlation coefficients of $r$-values and $p$-values were shown at the top right of the picture.

Abbreviations: PARC, pulmonary and activation-regulated chemokine; WBC, white blood cells; Hb, hemoglobin; Plt, blood platelet; Neut, neutrophil granulocyte; Eos, eosinophilic granulocyte; CRP, C-reactive protein.
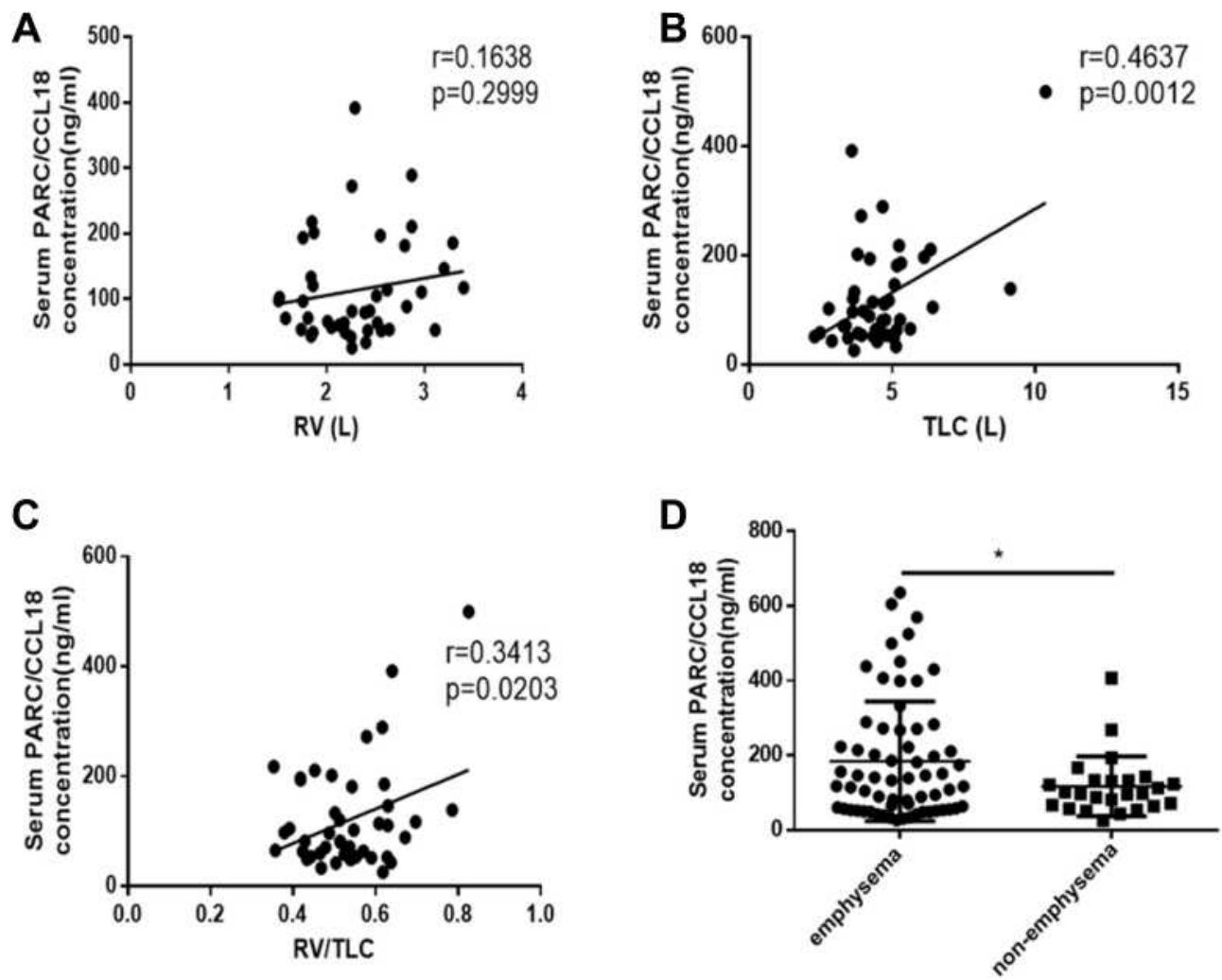

Figure 5 Correlation between RV (A), TLC (B), RV/TLC (C) and serum PARC level, respectively. (D) shows the comparison of serum PARC/CCLI8 concentration in emphysema and non-emphysema patients. The line represents the regression line of correlation analysis, Pearson correlation coefficients of r-values and $\mathrm{p}$-values were shown at the top right of the picture. The central horizontal line on each box represents the average, the error bars $5 \%$ and $95 \%$. $P$-values derived from the $t$-test. *Means $p<0.05$.

Abbreviations: PARC, pulmonary and activation-regulated chemokine; RV, residual volume; TLC, total lung capacity. 
Table 2 Clinical Characteristics of COPD Patients with Emphysema and Not

\begin{tabular}{|c|c|c|c|}
\hline & $\begin{array}{l}\text { Emphysema } \\
(n=61)\end{array}$ & $\begin{array}{l}\text { Non- } \\
\text { Emphysema } \\
(n=37)\end{array}$ & p value \\
\hline Age (yrs) & $70.48 \pm 1.02$ & $73.15 \pm 1.46$ & 0.127 \\
\hline $\begin{array}{l}\text { Male, n (\%)/ } \\
\text { Female }\end{array}$ & 57 (93.44\%) & $2 \mathrm{I}(56.76 \%)$ & $<0.0001$ \\
\hline $\begin{array}{l}\text { Disease } \\
\text { duration (yrs) }\end{array}$ & $9.94 \pm 1.02$ & $10.36 \pm 1.62$ & 0.814 \\
\hline Pack-years & $29.07 \pm 3.33$ & $14.26 \pm 2.85$ & 0.008 \\
\hline $\begin{array}{l}\text { Current smoker } \\
\text { (\%) }\end{array}$ & 8 (13.11\%) & 9 (24.32\%) & 0.155 \\
\hline LOS (days) & $7.734 \pm 0.45$ & $6.74 \pm 0.41$ & 0.136 \\
\hline CAT (score) & $26.4 I \pm 0.8 I$ & $22.79 \pm 0.88$ & 0.005 \\
\hline mMRC (score) & $2.85 \pm 0.122$ & $2.4 I \pm 0.16$ & 0.025 \\
\hline BMI $\left(\mathrm{kg} / \mathrm{m}^{2}\right)$ & $22.54 \pm 0.48$ & $23.79 \pm 0.70$ & 0.131 \\
\hline \multirow{2}{*}{\multicolumn{4}{|c|}{$\begin{array}{l}\text { COPD severity, } \\
\text { GOLD }\end{array}$}} \\
\hline & & & \\
\hline Mild, I & 6 (9.84\%) & 9 (24.32\%) & 0.053 \\
\hline Moderate, II & 12 (19.67\%) & 3 (8.11\%) & 0.123 \\
\hline Serve, III & 30 (49.18\%) & 19 (5I.35\%) & 0.835 \\
\hline Very serve, IV & 13 (2I.31\%) & 6 (16.22\%) & 0.536 \\
\hline WBC (/mL) & $8.5 I \pm 0.52$ & $8.85 \pm 0.66$ & 0.685 \\
\hline $\mathrm{Hb}(\mathrm{g} / \mathrm{L})$ & $|32| \pm 2.04$. & $127.9 \pm 3.19$ & 0.248 \\
\hline Plt (/mL) & $224.9 \pm 9.88$ & $217.9 \pm 12.97$ & 0.668 \\
\hline Neut (/mL) & $6.39 \pm 0.51$ & $6.09 \pm 0.57$ & 0.706 \\
\hline Eos $(/ \mathrm{mL})$ & $0.16 \pm 0.02$ & $0.20 \pm 0.03$ & 0.221 \\
\hline CRP (mg/L) & $33.27 \pm 6.03$ & $34.35 \pm 7.47$ & 0.912 \\
\hline FEVI (L) & $1.24 \pm 0.14$ & $1.35 \pm 0.21$ & 0.669 \\
\hline FVC & $2.15 \pm 0.17$ & $1.95 \pm 0.21$ & 0.470 \\
\hline $\mathrm{RV}(\mathrm{L})$ & $2.72 \pm 0.21$ & 1.910 .15 & 0.019 \\
\hline TLC (L) & $5.01 \pm 0.22$ & $4.06 \pm 0.25$ & 0.012 \\
\hline $\mathrm{RV} / \mathrm{TLC}$ & $0.55 \pm 0.02$ & $0.48 \pm 0.02$ & 0.044 \\
\hline PARC, $\mathrm{ng} / \mathrm{mL}$ & $184.4 \pm 19.86$ & $117.0 \pm 15.99$ & 0.049 \\
\hline
\end{tabular}

Notes: Analyzed by Student's t-test, Mann-Whitney test or chi-square test. Data are presented as mean $\pm S D$, number (with percentage in parentheses). Bold text means $\mathrm{p}<0.05$.

Abbreviations: COPD, chronic obstructive pulmonary disease; yrs, years; LOS, length of hospital stay; CAT, COPD Assessment Test; mMRC, modified British Medical Research Council; BMI, body mass index; WBC, white blood cells; $\mathrm{Hb}$, hemoglobin; Plt, blood platelet; Neut, neutrophil granulocyte; Eos, eosinophilic granulocyte; CRP, C-reactive protein; RV, residual volume; TLC, total lung capacity; PARC, pulmonary and activation-regulated chemokine. outcome and PARC, age, LOS and BMI as independent variables were carried out. The results showed that PARC level was an independent risk factor of ICS application $(\mathrm{OR}=1.092,95 \%$ CI (1.009-1.192), $\mathrm{p}=0.049)$. Multivariate logistic regression of factors associated with ICS application is shown in Table 4. A ROC curve was then used to determine the cutoff value for serum levels of PARC/ CCL18 that detect the ICS application. The area under the curve was 0.73 , and the cutoff value was $81.71 \mathrm{ng} / \mathrm{mL}$, the sensitivity was 0.719 , and the specificity was 0.68 ( $\mathrm{p}$ value $=0.003$ ) (Figure 6).

\section{Discussion}

In this retrospective study, 98 COPD patients and 60 healthy volunteers were recruited. Relationships between serum PARC/CCL18 levels and clinical features, blood cell count, CRP, lung functions and ICS application were discussed in patients with COPD. We found that serum PARC/CCL18 level in COPD population was significantly higher than that in healthy people (162.56 vs $85.09 \mathrm{ng} / \mathrm{mL}$, $\mathrm{p}=0.003)$. There was a positive correlation between PARC/ CCL18 and CRP $(p<0.0001)$, which represents the patients' inflammatory severity. COPD patients were then classified into emphysema and non-emphysema group according to the CT report. Patients in the emphysema group had significantly higher serum levels of PARC/ CCL18 than those in the non-emphysema group (184.4 vs $117.0 \mathrm{ng} / \mathrm{mL}, \mathrm{p}=0.049$ ). TLC and $\mathrm{RV} / \mathrm{TLC}$ were linear positive correlation with serum levels of PARC/CCL18 $(p=0.001,0.020$, respectively). These results show a clear relationship between serum PARC/CCL18 levels and severity of emphysema in patients with COPD. Furthermore, serum PARC/CCL18 levels were predictive for the application of ICS $(p=0.003)$. The area under the curve was 0.73 , and the cutoff value was $81.71 \mathrm{ng} / \mathrm{mL}$, which means when $81.71 \mathrm{ng} / \mathrm{mL}$ was selected as the critical point, serum PARC higher than $81.71 \mathrm{ng} / \mathrm{mL}$ had a certain reference value for ICS use in hospitalized COPD patients.

PARC/CCL18 is expressed by dendritic cells and macrophages and can be highly induced by inflammatory stimuli $^{31}$ and there are a lot of evidences that PARC/ CCL18 is associated with human diseases, especially lung diseases ${ }^{32-34}$ For example, it has been shown that PARC/CCL18 induces lung fibroblasts to synthesize collagen, thereby promoting fibrosis and deterioration of lung 
Table 3 Clinical Characteristics of COPD Patients with ICS and Not

\begin{tabular}{|c|c|c|c|}
\hline & $\begin{array}{c}\text { ICS } \\
(n=59)\end{array}$ & $\begin{array}{c}\text { Non-ICS } \\
(n=39)\end{array}$ & p value \\
\hline Age (yrs) & $73.32 \pm 1.13$ & $68.36 \pm 1.12$ & 0.001 \\
\hline Male, n (\%)/Female & 52 (88. $14 \%)$ & 31 (79.49\%) & 0.244 \\
\hline Disease duration (yrs) & $11.18 \pm 1.25$ & $8.62 \pm 1.15$ & 0.148 \\
\hline Pack-years & $\begin{array}{c}17.34 \\
\pm 20.16\end{array}$ & $29.21 \pm 28.49$ & 0.067 \\
\hline Current smoker (\%) & II (I8.64\%) & $6(15.38 \%)$ & 0.677 \\
\hline LOS (days) & $8.000 \pm 0.47$ & $6.49 \pm 0.37$ & 0.020 \\
\hline CAT (score) & $25.84 \pm 0.94$ & $24.00 \pm 0.7 \mid$ & 0.148 \\
\hline mMRC (score) & $2.80 \pm 0.13$ & $2.52 \pm 0.14$ & 0.146 \\
\hline BMI $\left(\mathrm{kg} / \mathrm{m}^{2}\right)$ & $22.30 \pm 0.50$ & $23.99 \pm 0.62$ & 0.036 \\
\hline \multicolumn{4}{|l|}{$\begin{array}{l}\text { COPD severity, } \\
\text { GOLD }\end{array}$} \\
\hline Mild, I & I3 (22.03\%) & $6(15.38 \%)$ & 0.415 \\
\hline Moderate, II & $16(27.11 \%)$ & $9(23.08 \%)$ & 0.65 \\
\hline Serve, III & $18(30.51 \%)$ & 17 (43.59\%) & 0.186 \\
\hline Very serve, IV & 12 (20.34\%) & 7 (17.95\%) & 0.770 \\
\hline WBC (/mL) & $8.05 \pm 0.53$ & $8.83 \pm 0.63$ & 0.691 \\
\hline $\mathrm{Hb}(\mathrm{g} / \mathrm{L})$ & $|3| .0 \pm 2.25$ & $130.0 \pm 2.80$ & 0.780 \\
\hline Plt (/mL) & $211.2 \pm 9.36$ & $237.8 \pm 13.20$ & 0.094 \\
\hline Neut (/mL) & $6.33 \pm 0.50$ & $6.21 \pm 0.6 \mathrm{I}$ & 0.885 \\
\hline Eos $(/ \mathrm{mL})$ & $0.18 \pm 0.02$ & $0.17 \pm 0.03$ & 0.735 \\
\hline CRP (mg/L) & $39.95 \pm 7.22$ & $24.96 \pm 4.7$ & 0.114 \\
\hline FEVI & $1.33 \pm 0.12$ & $1.30 \pm 0.14$ & 0.849 \\
\hline FVC & $2.10 \pm 0.14$ & $2.02 \pm 0.16$ & 0.696 \\
\hline $\mathrm{RV}(\mathrm{L})$ & $2.55 \pm 0.28$ & $2.27 \pm 0.13$ & $0.44 I$ \\
\hline TLC (L) & $4.63 \pm 0.31$ & $4.46 \pm 0.21$ & 0.680 \\
\hline $\mathrm{RV} / \mathrm{TLC}$ & $0.54 \pm 0.02$ & $0.5 I \pm 0.02$ & 0.392 \\
\hline PARC, $\mathrm{ng} / \mathrm{mL}$ & $\begin{array}{c}209.7 \\
\pm 21.21\end{array}$ & $91.30 \pm 8.7$ & 0.003 \\
\hline
\end{tabular}

Notes: Analyzed by Student's $t$-test, Mann-Whitney test or chi-square test. Data are presented as mean $\pm S D$, number (with percentage in parentheses). Bold text means $\mathrm{p}<0.05$.

Abbreviations: COPD, chronic obstructive pulmonary disease; ICS, inhaled corticosteroids; yrs, years; LOS, length of hospital stay; CAT, COPD Assessment Test; mMRC, modified British Medical Research Council; BMI, body mass index; WBC, white blood cells; Hb, hemoglobin; Plt, blood platelet; Neut, neutrophil granulocyte; Eos, eosinophilic granulocyte; CRP, C-reactive protein; RV, residual volume; TLC, total lung capacity; PARC, pulmonary and activation-regulated chemokine.
Table 4 Multivariate Logistic Regression of Factors Associated with ICS Application

\begin{tabular}{|l|l|l|}
\hline Variables & OR $(\mathbf{9 5} \% \mathbf{C l})$ & p value \\
\hline Age $($ yrs $)$ & $0.99 I(0.98 I-I .002)$ & $0.05 I$ \\
LOS $($ days $)$ & $1.048(0.843-1.304)$ & $0.67 I$ \\
BMI $\left(\mathrm{kg} / \mathrm{m}^{2}\right)$ & $0.898(0.76 I-1.058)$ & 0.199 \\
PARC, $\mathrm{ng} / \mathrm{mL}$ & $1.092(\mathrm{I} .009-\mathrm{I} .192)$ & $\mathbf{0 . 0 4 9}$ \\
\hline
\end{tabular}

Note: Bold text means $\mathrm{p}<0.05$.

Abbreviations: OR, odds ratio; $\mathrm{Cl}$, confidence interval; $\mathrm{LOS}$, length of hospital stay; BMI, body mass index; PARC, pulmonary and activation-regulated chemokine.

function. ${ }^{35}$ Recent studies have found that PARC/CCL18 plays an important role in the pathogenesis of COPD and is associated with the onset, progression, and severity of COPD. ${ }^{36-39}$ Kelly et $\mathrm{al}^{40}$ found that, compared with healthy population, serum PARC/CCL18 level in COPD patients was significantly higher, and serum PARC/CCL18 expression was significantly enhanced in COPD patients in the acute exacerbation phase. This study also showed that the serum PARC/CCL18 level of hospitalized COPD patients was higher than that of healthy people, which is consistent with the above research results.

In recent years, studies ${ }^{41}$ have shown that CRP concentration in patients with COPD is significantly higher than that in healthy controls. Consistent with previous study, ${ }^{42}$ this

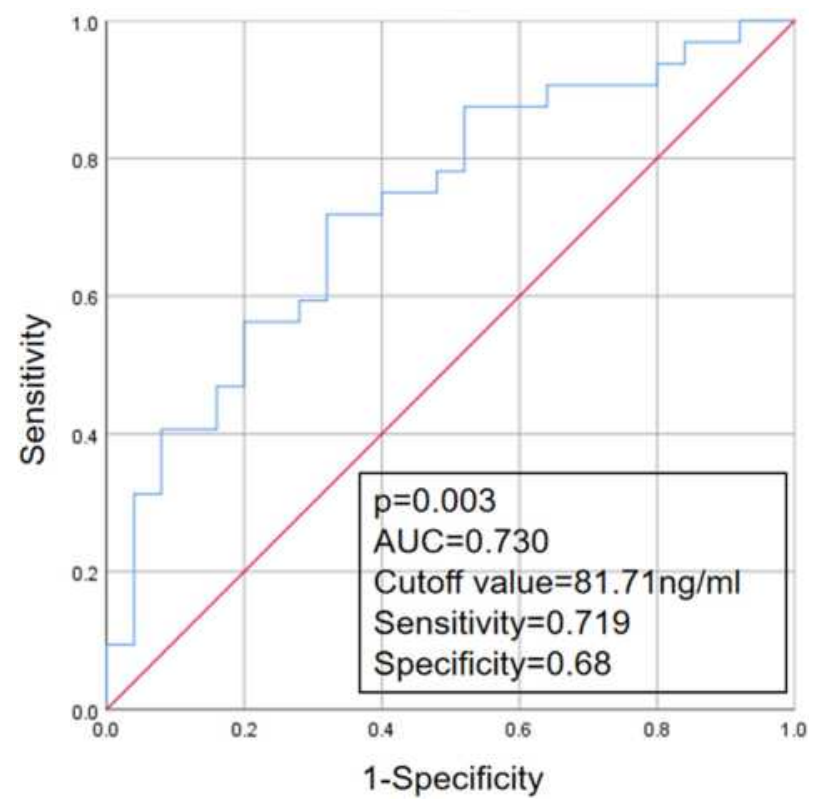

Figure 6 ROC curve analysis of PARC/CCLI8 for ICS application. Abbreviation: AUC, area under the curve. 
study reported that serum PARC/CCL18 presents significant associations with CRP of the COPD patients. It suggests that PARC/CCL18 may also be highly correlated with the severity of inflammation in the body. When the body is in the state of acute infection, CRP is synthesized and secreted by hepatocytes in large quantities under the stimulation of inflammatory factor IL- $6,{ }^{43}$ bind to and adhere to the surface of pathogens, start the immune phagocytosis of the body, and induce the production of complement to participate in the body's immunity, kill pathogens.

Lung function is a long-term predictor of mortality and morbidity in COPD. ${ }^{18-22}$ In a genome-wide association study, PARC/CCL18 was found involved in lung function phenotypes. $^{26}$ In the present study, we found that PARC/ CCL18 levels were higher in COPD patients with emphysema than in those without emphysema $(p<0.05)$ and the major correlation of PARC/CCL18 with pulmonary function was TLC and RV/TLC, which could be highly influenced by airway remodeling. RV increases with the increase of the thickness of the airway wall or the decrease of the lumen diameter of the middle airway. Meanwhile, TLC also increases with the increase of RV. A cross-sectional study of COPD patients reported an association between elevated serum PARC/ CCL18 levels and reduced FEV1. ${ }^{44}$ However, there were no obvious correlation between PARC/CCL18 level and FEV1, FEV1\%, PEF, DLCO observed in this study. These results imply that PARC/CCL18 is not significantly associated with airflow obstruction and diffusion capacity, but is strongly associated with changes in lung volume in COPD.

ICS reduce inflammation in the airways. However, unlike in asthma, their use in COPD is controversial. ${ }^{45-47}$ Currently, there is no research on the relationship between ICS and PARC/CCL18. In the present study, PARC/ CCL18 levels were higher in COPD patients applied ICS than those not. Multivariate logistic regression showed PARC/CCL18 was associated with ICS application and ROC curves draw a conclusion that serum PARC/CCL18 levels were predictive for the application of ICS.

We verified the increased expression of PARC/CCL18 in the serum of hospitalized COPD patients. For the first time, PARC/CCL18 level was found to predict the application of ICS in hospitalized COPD patients. This study also has some limitations. This study is a retrospective study at a single institute and the study size was small. The second limitation is lack of long-term follow-up data and survival analysis. The diagnostic value of serum
PARC/CCL18 level in COPD should be further explored by expanding the sample size and a prospective cohort study is needed in the future.

\section{Conclusions}

In conclusion, PARC/CCL18 is significantly increased in COPD and show positive correlation with severity of inflammation and emphysema. This study also demonstrated that PARC/CCL18 is a predictor of ICS application in hospitalized COPD patients. Thus, measuring serum PARC/CCL18 levels may help the COPD patients' management.

\section{Abbreviations}

PARC, pulmonary and activation-regulated chemokine; CCL18, chemokine ligand 18; COPD, chronic obstructive pulmonary disease; ICS, inhaled corticosteroids; yrs, years; LOS, length of hospital stay; CAT, COPD Assessment Test; mMRC, modified British Medical Research Council; BMI, body mass index; WBC, white blood cells; Hb, hemoglobin; Plt, blood platelet; neut, neutrophil granulocyte; Eos, eosinophilic granulocyte; CRP, C-reactive protein; RV, residual volume; TLC, total lung capacity; FEV1, forced expiratory volume in the 1st second; FVC, forced vital capacity; PEF, peak expiratory flow; DLCO, carbon monoxide diffusion capacity; VC, vital capacity; GOLD, Global Initiative for Obstructive Lung Disease; AUC, area under the curve.

\section{Data Sharing Statement}

All data generated or analyzed during this study are included in this published article.

\section{Ethics Approval and Consent to Participate}

All experiments performed in this study are in accordance with the principles stated in the Declaration of Helsinki. The study was approved by the Ethics Committee of Shanghai 10th People's Hospital (No. 20KT75). Patients' formed consents of their clinical data and blood samples for scientific research and publication were obtained.

\section{Acknowledgments}

We would like to thank all the patients who donate their biological samples. 


\section{Author Contributions}

All authors made a significant contribution to the work reported, whether that is in the conception, study design, execution, acquisition of data, analysis and interpretation, or in all these areas; took part in drafting, revising or critically reviewing the article; gave final approval of the version to be published; have agreed on the journal to which the article has been submitted; and agree to be accountable for all aspects of the work. All authors had read and approved the manuscript. Co-corresponding authors: Shuanshuan Xie and Changhui Wang.

\section{Funding}

This work was supported by the Shanghai Science and Technology Commission (No. 19411969500). Changhui Wang is the recipient of the foundations and was responsible for editing manuscript in our study.

\section{Disclosure}

The authors declare that they have no conflicts of interest for this work.

\section{References}

1. Fitzmaurice C, Allen C, Barber RM; Global Burden of Disease Cancer $\mathrm{C}$, et al. Global, regional, and national cancer incidence, mortality, years of life lost, years lived with disability, and disability-adjusted life-years for 32 cancer groups, 1990 to 2015: a systematic analysis for the global burden of disease study. JAMA Oncol. 2017;3:524-548. doi:10.1001/jamaoncol.2016.5688

2. Viniol C, Vogelmeier CF. Exacerbations of COPD. Eur Respir Rev. 2018;27:170103. doi:10.1183/16000617.0103-2017

3. Katz R. Biomarkers and surrogate markers: an FDA perspective. NeuroRx. 2004;1:189-195. doi:10.1602/neurorx.1.2.189

4. Gunther C, Bello-Fernandez C, Kopp T, et al. CCL18 is expressed in atopic dermatitis and mediates skin homing of human memory $\mathrm{T}$ cells. J Immunol. 2005;174:1723-1728. doi:10.4049/jimmunol.174.3.1723

5. Legendre B, Tokarski C, Chang Y, et al. The disulfide bond between cysteine 10 and cysteine 34 is required for CCL18 activity. Cytokine. 2013;64:463-470. doi:10.1016/j.cyto.2013.04.028

6. Guan P, Burghes AH, Cunningham A, et al. Genomic organization and biological characterization of the novel human CC chemokine DC-CK-1/PARC/MIP-4/SCYA18. Genomics. 1999;56:296-302. doi:10.1006/geno.1998.5635

7. Adema GJ, Hartgers F, Verstraten R, et al. A dendritic-cell-derived $\mathrm{C}-\mathrm{C}$ chemokine that preferentially attracts naive $\mathrm{T}$ cells. Nature. 1997;387:713-717. doi:10.1038/42716

8. Catusse J, Wollner S, Leick M, Schrottner P, Schraufstatter I, Burger M. Attenuation of CXCR4 responses by CCL18 in acute lymphocytic leukemia B cells. J Cell Physiol. 2010;225:792-800. doi:10.1002/jep.22284

9. Vulcano M, Struyf S, Scapini P, et al. Unique regulation of CCL18 production by maturing dendritic cells. $J$ Immunol. 2003;170:3843-3849. doi:10.4049/jimmunol.170.7.3843

10. Gavala ML, Kelly EA, Esnault S, et al. Segmental allergen challenge enhances chitinase activity and levels of CCL18 in mild atopic asthma. Clin Exp Allergy. 2013;43:187-197. doi:10.1111/cea.12032
11. de Nadai P, Charbonnier AS, Chenivesse C, et al. Involvement of CCL18 in allergic asthma. J Immunol. 2006;176:6286-6293. doi:10.4049/jimmunol.176.10.6286

12. Atamas SP, Luzina IG, Choi J, et al. Pulmonary and activation-regulated chemokine stimulates collagen production in lung fibroblasts. Am J Respir Cell Mol Biol. 2003;29:743-749. doi: $10.1165 / \mathrm{rcmb} .2003-0078 \mathrm{OC}$

13. Kraaijeveld AO, de Jager SC, de Jager WJ, et al. CC chemokine ligand-5 (CCL5/RANTES) and CC chemokine ligand-18 (CCL18/ PARC) are specific markers of refractory unstable angina pectoris and are transiently raised during severe ischemic symptoms. Circulation. 2007;116:1931-1941. doi:10.1161/CIRCULATIONAHA.107.706986

14. Prasse A, Pechkovsky DV, Toews GB, et al. CCL18 as an indicator of pulmonary fibrotic activity in idiopathic interstitial pneumonias and systemic sclerosis. Arthritis Rheum. 2007;56:1685-1693. doi: $10.1002 /$ art. 22559

15. Struyf S, Schutyser E, Gouwy M, et al. PARC/CCL18 is a plasma CC chemokine with increased levels in childhood acute lymphoblastic leukemia. Am J Pathol. 2003;163:2065-2075. doi:10.1016/S00029440(10)63564-X

16. Munoz-Esquerre M, Lopez-Sanchez M, Escobar I, et al. Systemic and pulmonary vascular remodelling in chronic obstructive pulmonary disease. PLoS One. 2016;11:e0152987. doi:10.1371/journal. pone. 0152987

17. Hieshima K, Imai T, Baba M, et al. A novel human $\mathrm{CC}$ chemokine PARC that is most homologous to macrophage-inflammatory protein-1 alpha/LD78 alpha and chemotactic for T lymphocytes, but not for monocytes. J Immunol. 1997;159:1140-1149.

18. Burney PG, Hooper R. Forced vital capacity, airway obstruction and survival in a general population sample from the USA. Thorax. 2011;66:49-54. doi:10.1136/thx.2010.147041

19. Weiss ST, Segal MR, Sparrow D, Wager C. Relation of FEV1 and peripheral blood leukocyte count to total mortality. The Normative Aging Study. Am J Epidemiol. 1995;142:493-498; discussion 499-503. doi:10.1093/oxfordjournals.aje.a117665

20. Schunemann HJ, Dorn J, Grant BJ, Winkelstein W, Trevisan M. Pulmonary function is a long-term predictor of mortality in the general population: 29-year follow-up of the Buffalo Health Study. Chest. 2000;118:656-664. doi:10.1378/chest.118.3.656

21. Young RP, Hopkins R, Eaton TE. Forced expiratory volume in one second: not just a lung function test but a marker of premature death from all causes. Eur Respir J. 2007;30:616-622. doi:10.1183/ 09031936.00021707

22. Myint PK, Luben RN, Surtees PG, et al. Respiratory function and self-reported functional health: EPIC-Norfolk population study. Eur Respir J. 2005;26:494-502. doi:10.1183/09031936.05.00023605

23. Pinto-Plata V, Toso J, Lee $\mathrm{K}$, et al. Profiling serum biomarkers in patients with COPD: associations with clinical parameters. Thorax. 2007;62:595-601. doi:10.1136/thx.2006.064428

24. Hurst JR, Donaldson GC, Perera WR, et al. Use of plasma biomarkers at exacerbation of chronic obstructive pulmonary disease. $\mathrm{Am}$ $J$ Respir Crit Care Med. 2006;174:867-874. doi:10.1164/ rccm.200604-506OC

25. Sin DD, Miller BE, Duvoix A, et al.; Investigators E. Serum PARC/ CCL-18 concentrations and health outcomes in chronic obstructive pulmonary disease. Am $J$ Respir Crit Care Med. 2011;183:1187-1192. doi:10.1164/rccm.201008-1220OC

26. Yao TC, Du G, Han L, et al. Genome-wide association study of lung function phenotypes in a founder population. J Allergy Clin Immunol. 2014;133:248. doi:10.1016/j.jaci.2013.06.018

27. Misof BM, Moreira CA, Klaushofer K, Roschger P. Skeletal implications of chronic obstructive pulmonary disease. Curr Osteoporos Rep. 2016;14:49-53. doi:10.1007/s11914-016-0301-8

28. Tin SS, Wiwanitkita V. Osteoporosis in chronic obstructive pulmonary disease. Lung India. 2015;32:200. doi:10.4103/09702113.152674 
29. Kiyokawa H, Muro S, Oguma T, et al. Impact of COPD exacerbations on osteoporosis assessed by chest CT scan. COPD. 2012;9:235-242. doi:10.3109/15412555.2011.650243

30. Vestbo J, Anderson W, Coxson HO, et al.; investigators E. Evaluation of COPD Longitudinally to Identify Predictive Surrogate End-points (ECLIPSE). Eur Respir J. 2008;31:869-873. doi:10.1183/ 09031936.00111707

31. Schutyser E, Richmond A, Van Damme J. Involvement of CC chemokine ligand 18 (CCL18) in normal and pathological processes. J Leukoc Biol. 2005;78:14-26. doi:10.1189/jlb.1204712

32. Tsicopoulos A, Chang Y, Ait Yahia S, de Nadai P, Chenivesse C. Role of CCL18 in asthma and lung immunity. Clin Exp Allergy. 2013;43:716-722. doi:10.1111/cea.12065

33. Hagg DA, Olson FJ, Kjelldahl J, et al. Expression of chemokine (C-C motif) ligand 18 in human macrophages and atherosclerotic plaques. Atherosclerosis. 2009;204:e15-20. doi:10.1016/j. atherosclerosis.2008.10.010

34. Chen J, Yao Y, Gong C, et al. CCL18 from tumor-associated macrophages promotes breast cancer metastasis via PITPNM3. Cancer Cell. 2011;19:541-555. doi:10.1016/j.ccr.2011.02.006

35. Islam SA, Ling MF, Leung J, Shreffler WG, Luster AD. Identification of human CCR8 as a CCL18 receptor. $J$ Exp Med. 2013;210:1889-1898. doi:10.1084/jem.20130240

36. Guzel A, Karadag A, Okuyucu A, Alacam H, Kucuk Y. The evaluation of serum surfactant protein D (SP-D) levels as a biomarker of lung injury in tuberculosis and different lung diseases. Clin Lab. 2014;60:1091-1098. doi:10.7754/Clin.Lab.2013.130323

37. Sondergaard J, Halling A. The PROTECCT-M study: a cohort study investigating associations between novel specific biomarkers, patient-related, healthcare system markers and the trajectory of COPD patients treated in primary care. BMC Pulm Med. 2014;14:88. doi:10.1186/1471-2466-14-88

38. Agusti A, Sin DD. Biomarkers in COPD. Clin Chest Med. 2014;35:131-141. doi:10.1016/j.ccm.2013.09.006
39. Johansson SL, Tan Q, Holst R, et al. Surfactant protein D is a candidate biomarker for subclinical tobacco smoke-induced lung damage. Am J Physiol Lung Cell Mol Physiol. 2014;306:L887-895. doi:10.1152/ajplung.00340.2013

40. Kelly E, Owen CA, Pinto-Plata V, Celli BR. The role of systemic inflammatory biomarkers to predict mortality in chronic obstructive pulmonary disease. Expert Rev Respir Med. 2013;7:57-64. doi:10.1586/ers. 12.82

41. Eid AA, Ionescu AA, Nixon LS, et al. Inflammatory response and body composition in chronic obstructive pulmonary disease. Am J Respir Crit Care Med. 2001;164:1414-1418. doi:10.1164/ ajrccm.164.8.2008109

42. Mullerova H, Maselli DJ, Locantore N, et al. Hospitalized exacerbations of COPD: risk factors and outcomes in the ECLIPSE cohort. Chest. 2015;147:999-1007. doi:10.1378/chest.14-0655

43. Dev D, Wallace E, Sankaran R, et al. Value of C-reactive protein measurements in exacerbations of chronic obstructive pulmonary disease. Respir Med. 1998;92:664-667. doi:10.1016/S0954-6111(98) 90515-7

44. Pinto-Plata V, Casanova C, Mullerova H, et al. Inflammatory and repair serum biomarker pattern: association to clinical outcomes in COPD. Respir Res. 2012;13:71. doi:10.1186/1465-9921-13-71

45. Ejiofor S, Turner AM. Pharmacotherapies for COPD. Clin Med Insights Circ Respir Pulm Med. 2013;7:17-34. doi:10.4137/ CCRPM.S7211

46. Barnes PJ. Inhaled corticosteroids in COPD: a controversy. Respiration. 2010;80:89-95. doi:10.1159/000315416

47. Kaplan AG. Applying the wisdom of stepping down inhaled corticosteroids in patients with COPD: a proposed algorithm for clinical practice. Int J Chron Obstruct Pulmon Dis. 2015;10:2535-2548. doi:10.2147/COPD.S93321

\section{Publish your work in this journal}

The International Journal of COPD is an international, peer-reviewed journal of therapeutics and pharmacology focusing on concise rapid reporting of clinical studies and reviews in COPD. Special focus is given to the pathophysiological processes underlying the disease, intervention programs, patient focused education, and self management protocols. This journal is indexed on PubMed Central, MedLine and CAS. The manuscript management system is completely online and includes a very quick and fair peer-review system, which is all easy to use. Visit http://www.dovepress.com/testimonials.php to read real quotes from published authors. 